\title{
Effect of Bt broccoli and resistant genotype of Plutella xylostella (Lepidoptera: Plutellidae) on development and host acceptance of the parasitoid Diadegma insulare (Hymenoptera: Ichneumonidae)
}

\author{
Xiaoxia Liu • Mao Chen • David Onstad • \\ Rick Roush $\cdot$ Anthony M. Shelton
}

Received: 22 July 2010/ Accepted: 27 November 2010/Published online: 23 December 2010

(C) Springer Science+Business Media B.V. 2010

\begin{abstract}
The ecological implications on biological control of insecticidal transgenic plants, which produce crystal (Cry) proteins from the soil bacterium Bacillus thuringiensis $(\mathrm{Bt})$, remain a contentious issue and affect risk assessment decisions. In this study, we used a unique system of resistant insects, Bt plants and a parasitoid to critically evaluate this issue. The effects of broccoli type (normal or expressing Cry1Ac protein) and insect genotype (susceptible or Cry1Ac-resistant) of Plutella xylostella L. (Lepidoptera: Plutellidae) were examined for their effects on the development and host foraging behavior of the parasitoid, Diadegma insulare (Cresson)
\end{abstract}

X. Liu · M. Chen · A. M. Shelton $(\square)$

Department of Entomology, Cornell University/ New York State Agricultural Experiment Station, 630 W. North St., Geneva, NY 14456, USA e-mail: ams5@cornell.edu

X. Liu

Department of Entomology, China Agricultural University, Beijing 100193, China

D. Onstad

Department of Crop Sciences, University of Illinois, Urbana, IL 61801, USA

\section{R. Roush}

Melbourne School of Land and Environment, Parkville Campus, University of Melbourne,

Melbourne, Vic 3010, Australia
(Hymenoptera: Ichneumonidae) over two generations. Parasitism rate and development of $D$. insulare were not significantly different when different genotypes (Bt-resistant or susceptible) of insect host larvae fed on non-Bt broccoli plants. D. insulare could not discriminate between resistant and susceptible genotypes of $P$. xylostella, nor between $\mathrm{Bt}$ and normal broccoli plants with different genotypes of $P$. xylostella feeding on them. No $D$. insulare could emerge from Bt broccoli-fed susceptible and heterozygous $P$. xylostella larvae because these larvae were unable to survive on $\mathrm{Bt}$ broccoli. The parasitism rate, developmental period, pupal and adult weights of $D$. insulare that had developed on Bt broccoli-fed Cry1Ac-resistant $P$. xylostella larvae were not significantly different from those that developed on non-Bt broccoli-fed larvae. Female $D$. insulare emerged from Cry1Ac-resistant $P$. xylostella that fed on Bt plants could successfully parasitize $P$. xylostella larvae. The life parameters of the subsequent generation of D. insulare from P. xylostella reared on Bt broccoli were not significantly different from those from nonBt broccoli. The Cry1Ac protein was detected in $P$. xylostella and in D. insulare when hosts fed on Bt broccoli. These results are the first to indicate that Cry1Ac did not harm the development or host acceptance of an important endoparasitoid after two generations of exposure. We suggest that using other Bt crops and resistant insect species would likely lead to similar conclusions about the safety of the presently used Bt proteins on parasitoids. 
Keywords Bacillus thuringiensis - Biosafety ·

Natural enemies - Transgenic crop · Host genotype

$\begin{array}{ll}\text { Abbreviations } \\ \text { RR } & \text { Cry1Ac-resistant strain or homozygous } \\ & \text { resistance genotype } \\ \text { RS } & \text { Heterozygous resistance genotype } \\ \text { SS } & \text { Susceptible strain or genotype } \\ \text { Bt } & \text { Bacillus thuringiensis }\end{array}$

\section{Introduction}

Development and commercialization of insect-resistant genetically modified (IRGM) crops expressing insecticidal proteins (Cry toxins) from bacterium Bacillus thuringiensis (Bt) have offered an alternative to traditional synthetic insecticides for control of important agricultural insect pests. The only currently available IRGM crops for commercial planting are $\mathrm{Bt}$ corn and Bt cotton. In 2009 these crops were grown on 50.4 million hectares in 25 countries (James 2009). Bt rice received regulatory approve in China in 2009 and will likely be commercialized in the near future (http://www.stee.agri.gov.cn/biosafety/spxx/ t20091022_819217.htm). Other IRGM crops are waiting in the wings, including Bt eggplant, cabbage and cauliflower (Shelton et al. 2008; Grzywacz et al. 2010).

The diamondback moth, Plutella xylostella (Lepidoptera: Plutellidae), is the most destructive insect pest of brassica crops worldwide. The estimated annual cost for controlling this insect two decades ago was US \$1 billion (Talekar and Shelton 1993). Like other transgenic crops, a range of brassica species expressing insecticidal proteins from Bt have been engineered to provide resistance to $P$. xylostella and other lepidopteran pests (Shelton et al. 2008). Our previous studies have demonstrated that brassica crops expressing $\mathrm{Bt}$ insecticidal proteins can effectively control P. xylostella (Metz et al. 1995; Tang et al. 1999, 2001; Cao et al. 1999, 2002, 2005; Shelton et al. 2000, 2008; Zhao et al. 2000, 2003, 2005).

Bt plants have provided economic benefits to growers and reduced the use of synthetic insecticides (Shelton et al. 2002; Qaim et al. 2008; Brookes and
Barfoot 2010), but there has been considerable discussion about whether they are compatible with natural enemies that help suppress pest population. Numerous studies have investigated the effects of $\mathrm{Bt}$ plants and Cry proteins on parasitoids and predators. Predators are usually generalists and feed on several different prey species and the effects of Bt plants on them have been found to be negligible (Romeis et al. 2006; Naranjo 2009), although others have disagreed (Lövei et al. 2009, but also see Shelton et al. 2009a, b). Lawo et al. (2010) reported that larvae of the green lacewing, Chrysoperla carnea (Neuroptera: Chrysopidae), were adversely affected when fed Bt (Cry1Ac) cotton-fed caterpillars. In contrast, the predators remained unaffected when feeding on Bt cotton-fed caterpillars from a Cry1Ac-resistant strain. This demonstrated that the adverse effects seen with the susceptible caterpillar strain were prey-quality mediated and supports the concept of using Bt toxin resistant strains as a way to test the sensitivity of beneficial arthropods to Cry toxins (Romeis et al. 2010).

Host-parasitoid relationships are more intimate because parasitoids usually complete their larval development in a single insect host. Negative impacts of $\mathrm{Bt}$ toxins on non-target parasitoids have been reported when susceptible insect hosts were used in some studies (Baur and Boethel 2003; Liu et al. 2005a, b, c; Sanders et al. 2007), although the negative impacts most likely were host-quality mediated. When resistant insect hosts were used in some studies, no negative effects of transgenic plants on parasitoids were found (Johnson 1997; Atwood et al. 1998; Schuler et al. 1999, 2004; Chen et al. 2008). However, the impact of transgenic plants on the subsequent performance of adult parasitoids when resistant hosts were used has not been explored.

Diadegma insulare (Cresson) (Hymenoptera: Ichneumonidae) is a solitary, host-specific larval endoparasitoid and is an important biological control agent of $P$. xylostella in North America (Xu et al. 2001a, b; Sarfraz et al. 2005). Although our previous studies (Chen et al. 2008) indicated that Cry1C, which is effective against about 35-40 species and differs in its insecticidal host range from the Cry1A toxins (Avisar et al. 2004), did not have any direct toxicity on $D$. insulare during the first generation when it fed on $P$. xylostella feeding on Cry1C broccoli, neither our study nor any other study has investigated the possible chronic or cumulative 
effects of Bt plants on subsequent generations of a parasitoid. Such longer term effects could be evident not only from direct toxicity, but from changes in the parasitoid's behavior. This is an important and yet uninvestigated question that has implications for both biological control and risk assessment of Bt crops.

Our resistant $P$. xylostella and Bt broccoli system allows us to investigate this question. For example, if $\mathrm{Bt}$ brassicas are commercialized for control of P. xylostella, D. insulare would likely be exposed in the field to different plant types (Bt and non-Bt plants) in the neighboring fields because a common strategy to delay the evolution of resistance to $\mathrm{Bt}$ plants is to use non-Bt plants as a refuge to conserve susceptible alleles (Bates et al. 2005). Likewise, as resistance to the $\mathrm{Bt}$ proteins evolves, parasitoids would also be exposed to different genotypes of insect hosts (resistant (RR), susceptible (SS) or heterozygous (RS) individuals). Thus, the interaction of Bt plants, genotypes of insect hosts and parasitoids might have complex effects, especially when viewed over multiple generations, including effects on the rate of resistance evolution.

The present study goes beyond the results of Chen et al. (2008) and other studies to explore whether host genotypes and plant types could affect the development and host acceptance behavior of $D$. insulare and its progeny over multiple generations. Specifically, the following objectives were addressed in this study: (1) determine if $D$. insulare could discriminate between resistant and susceptible genotypes of P. xylostella; (2) determine if $D$. insulare could discriminate plant types (Bt plants or non-Bt plants) hosting different resistance genotypes of $P$. xylostella, and; (3) quantify the effects of Cry1Ac broccoli plants on selected life history parameters of $D$. insulare when the plants are infested by RR, RS, and SS genotypes of $P$. xylostella for two generations.

\section{Materials and methods}

Insects

Three strains of $P$. xylostella were used: (1) a Cry1Ac-resistant strain (RR), which can survive on Cry1Ac Bt broccoli plants (Zhao et al. 2005); (2) a Cry1Ac-susceptible strain (SS, Geneva 88), which cannot survive on Cry1Ac Bt broccoli plants (Zhao et al. 2005); (3) a heterozygous strain (RS), which was developed by crossing RR with G88. The hymenopteran endoparasitoid, D. insulare, was originally field collected in Florida in 1999 and subsequently reared in our greenhouse according to the procedures of Xu et al. (2001a, b). Insects were kept in a climatic chamber at $27 \pm 1^{\circ} \mathrm{C}, 50 \pm 10 \% \mathrm{RH}$, and $16: 8 \mathrm{~h}$ photoperiod.

Bt broccoli plants

We used Brassica oleracea L., var. italica' Green Comet as the cultivar for our broccoli plants. The transgenic broccoli produces high levels of Cry1 Ac (Metz et al. 1995). To ensure the activity of the Bt broccoli, the plants were screened with the susceptible $P$. xylostella neonates when plants were 4-5week-old. In all the studies reported in this paper, broccoli plants with 8 true leaves were used and analysis by ELISA indicated that the Cry1Ac protein level was $12.33 \pm 1.62 \mu \mathrm{g} / \mathrm{g} \quad(n=7)$ fresh leaf tissue.

Survival and development of different genotypes of $P$. xylostella fed on Bt or non-Bt

broccoli plants

To evaluate the effect of $\mathrm{Bt}$ broccoli plants on different genotypes of $P$. xylostella, 20 neonates of RR, RS and SS genotypes were fed leaves from Cry1Ac broccoli or non-Bt broccoli in a Plexiglas cylinder cage $(10 \mathrm{~cm} \times 10 \mathrm{~cm} \times 20 \mathrm{~cm})$. In order to keep a leaf fresh, the leaf petiole was placed in a $100 \mathrm{ml}$ flask with water. The old leaves were replaced with new ones every 2 days. All six treatments were replicated 4 times. The survival rate at 3 days and the duration of the egg and larval period, the length of the pupal period and the percent pupation and the pupal weight, and the adult emergence rate were recorded. The experiment was conducted in a climatic chamber at $27 \pm 1{ }^{\circ} \mathrm{C}$, $50 \pm 10 \% \mathrm{RH}$, and 16:8 h photoperiod.

Can D. insulare discriminate different genotypes of P. xylostella?

Choice tests were conducted in $1 \mathrm{~m} \times 1 \mathrm{~m} \times 1 \mathrm{~m}$ netted cages. Fifty $P$. xylostella second instars (either $\mathrm{RR}, \mathrm{RS}$, or SS) of a single genotype were placed on a 
non-Bt broccoli leaf with its petiole inserted in a $100 \mathrm{ml}$ flask filled with water for 1 day before being presented to the natural enemy. One flask hosting a different genotype of DBM (RR, RS or SS) was placed in a triangle with similar distance between the flasks. Three pairs of 3-day-old adult $D$. insulare were released in the center of the triangle in each cage. A flask of $10 \%$ sugar solution with a wick was placed into each cage as a food source for $D$. insulare. After $48 \mathrm{~h}$, the P. xylostella larvae were retrieved and transferred into diet cups (Shelton et al. 1991) and allowed to develop into P. xylostella adults or D. insulare adults. All 50 caterpillars from one leaf were placed in one diet cup. All three treatments were replicated six times. Parasitism rates (\% parasitism $=$ (number of $D$. insulare/(number of $D$. insulare + number of $P$. xylostella) $* 100$ ) caused by $D$. insulare on each genotype of $P$. xylsotella were recorded.

Can D. insulare discriminate plant types hosting different genotypes of $P$. xylostella?

In order to evaluate whether the parasitoids could discriminate plant types hosting different genotypes of $P$. xylostella, a $2 \times 3$ design (plant types: Bt or non-Bt $) \times(P$. xylostella genotypes: RR, RS and SS $)$ was utilized. Each cage $(1 \mathrm{~m} \times 1 \mathrm{~m} \times 1 \mathrm{~m})$ had six treatments: RR on Cry1Ac plant, RS on Cry1Ac plant, SS on Cry1Ac plant, RR on non-Bt plant, RS on non-Bt plant, and SS on non-Bt plant. Each treatment had $50 \mathrm{P}$. xylostella second instars (RR, $\mathrm{RS}$, or RS) on each leaf and each leaf was placed in the center of the cage in a flask and evenly separated. $P$. xylostella larvae were allowed to feed on the corresponding leaves for 1 day before being exposed to $D$. insulare. Four pairs of new emerged $D$. insulare adults were put into a Plexiglas cylinder cage $(10 \mathrm{~cm} \times 10 \mathrm{~cm} \times 20 \mathrm{~cm})$ with sugar water to mate for 3 days. Then the four mated females were released into the center of each cage. After $48 \mathrm{~h}$, the larvae were retrieved and transferred to diet cups and allowed to develop into P. xylostella adults or D. insulare adults. Parasitism rates (percentages) caused by $D$. insulare on each genotype of $P$. xylsotella were recorded. The six treatments were replicated six times.
Effect of plant type and host genotype

on the development of the $F_{1}$ parasitoid

Because the first experiment of survival of different genotypes of $P$. xylostella fed on $\mathrm{Bt}$ and our earlier studies (Zhao et al. 2000, 2005) showed that the RS and SS strains could not survive on Cry1Ac broccoli plants, here were only four treatments in this study: $\mathrm{RR}$ on Bt broccoli, RR on non-Bt broccoli, RS on non-Bt broccoli and SS on non-Bt broccoli. For the RR treatments, 50 P. xylostella larvae were placed on a Cry1Ac leaf in a $100 \mathrm{ml}$ flask filled with water and then placed in a Plexiglas cylinder cage $(10 \mathrm{~cm} \times$ $10 \mathrm{~cm} \times 20 \mathrm{~cm}$ ) for 1 day. Then two pairs $D$. insulare were released into the cage and, after $24 \mathrm{~h}$, the parasitoids were removed and the $P$. xylostella RR larvae were transferred onto a new Cry1Ac broccoli leaf. The P. xylostella larvae were kept in the cage until D. insulare pupa or P. xylostella adult emergence. Old Cry1Ac leaves were replaced with fresh ones as needed. Each $D$. insulare pupa was weighed and placed individually into a $30 \mathrm{ml}$ cup. Moreover, the developmental time of $D$. insulare (from oviposition to adult emergence), adult longevity (without food) and dry weight were recorded at the end. RR, RS and SS larvae fed on non-Bt leaf in each cage were also set up as described above and exposed to $D$. insulare with the same data endpoints being recorded. The four different treatments were replicated 4 times.

Development of $\mathrm{F}_{2}$ parasitoids reared from different genotypes of $P$. xylostella exposed to Bt or non-Bt broccoli

In order to evaluate whether Bt broccoli plants and $P$. xylostella genotypes would affect the ability of $D$. insulare's progeny to utilize a susceptible host, we studied the development of the second generation $D$. insulare whose parents emerged from the different genotypes of $P$. xylostella larvae on $\mathrm{Bt}$ or non- $\mathrm{Bt}$ broccoli. Two pairs of $D$. insulare that developed from RR on Bt, RR on non-Bt broccoli, RS on non-Bt broccoli, and SS on non-Bt broccoli, separately, were introduced to $50 \mathrm{SS}$ larvae fed on non-Bt broccoli plants for 1 day. After $24 \mathrm{~h}$, the parasitoids were removed and the $P$. xylostella larvae were transferred onto a new non-Bt broccoli leaf. All four treatments 
were replicated 4 times. Parasitism rate, the developmental time, pupal weight, adult longevity (without food) and dry weight of $F_{2} D$. insulare were recorded.

Quantification of Cry1Ac in P. xylostella and in D. insulare

The amounts of Cry1Ac in larvae, pupae and adults of the RR genotype, which were fed on Bt broccoli from neonates, and the Cry1Ac in larvae, pupae and adults of $D$. insulare were monitored by ELISA using the EnviroLogix Cry1Ac/Cry1Ab kit. RR neonates were fed on Bt broccoli until the second instar, then the larvae were provided to $D$. insulare for $48 \mathrm{~h}$. The parasitized larvae were fed on Bt broccoli to develop into P. xylostella adults or D. insulare pupae. The mature larvae, pupae, adults and pupal coccons were sampled and kept in Eppendorf vials to detect the transfer and accumulation of Cry1Ac protein in D. insulare.

Each sample included 20 larvae, pupae or adults, separately, and was ground and homogenized in $0.3 \mathrm{ml}$ Extraction/dilution buffer (EnviroLogix). In order to keep samples from contamination, each sample were washed three times with dilution buffer prior to the analysis. ELISA was conducted according to the manufacturer's instructions. Based on preliminary tests, sample extractions were diluted by 1:50 for $P$. xylostella larvae, by 1:20 for the pupae and adults of $P$. xylostella and the larvae and pupae of $D$. insulare, and by undiluted extraction for $D$. insulare adults. Each treatment was replicated 5-7 times. The optical density value of sample was measured using a microplate reader set at $450 \mathrm{~nm}$. The larvae fed on non-Bt broccoli were used as the controls.

Bioactivity of Cry1Ac after ingestion by P. xylostella larvae

To confirm that $D$. insulare was exposed to active Cry1Ac toxin when it developed inside Cry1Acresistant $P$. xylostella larvae, the biological activity of the Cry1Ac toxin being consumed by Cry1Acresistant $P$. xylostella was checked according to the methods of Chen et al. (2008). P. xylostella second instars from the Cry1Ac-resistant (RR) strain were fed Cry1Ac plants. Non-Bt broccoli plants were used as control. After RR larvae fed on the Cry1Ac plants for 2 days, they were collected into separate $1.5 \mathrm{ml}$ Eppendorf vials. The RR larvae were washed with distilled water 4 times then ground with a pestle in $500 \mu \mathrm{l} \mathrm{Cry1Ac}$ toxin extraction buffer (supplied in Cry1Ac ELISA kit, EnviroLogix Inc., Portland, ME). The solution was diluted to 5,000 $\mu$ and was applied to cabbage leaf disks that were fed to Cry1Acsusceptible (SS) larvae. Ten second instars from the SS strain were placed on each of the leaf disks inside 30 -ml plastic cups with 5 replications. Mortality was determined after 3 days at $27 \pm 1{ }^{\circ} \mathrm{C}$.

\section{Statistical analyses}

Data were analyzed using one-way ANOVA and differences between treatment means were tested with the Tukey test at a 5\% level of significance. All statistical analyses were conducted using SPSS 17.0 Windows (1998) (SPSS, Chicago, IL).

\section{Results}

Survival and development of different genotypes of $P$. xylostella fed Bt or non-Bt broccoli plants

The results confirmed that RS and SS larvae could not survive on Bt plants, while Cry1Ac-resistant neonates could (Table 1). The egg to larval period and pupal period of RR fed Bt plants was significantly longer in comparison with the RS and SS strains fed on non-Bt plants. No significant differences were found between RR fed Cry1Ac plants and RR fed non-Bt plants. The $P$. xylostella pupation rates, pupal weights, and adult emergence rates were not significantly different between the treatments of $\mathrm{RR}$ on Bt broccoli, RR on non-Bt broccoli, RS on non-Bt broccoli and SS on non-Bt broccoli.

Can $D$. insulare discriminate different genotypes of P. xylostella?

The results show that $D$. insulare did not discriminate between different genotypes of $P$. xylostella. The parasitism rates caused by $D$. insulare on RR, RS and SS genotypes hosted on non-Bt broccoli plants were $30.14 \pm 6.51 \%, 21.45 \pm 3.33 \%$ and $28.44 \pm 6.98 \%$ 
Table 1 Development of different genotypes of Plutella xylostella on Bt or non-Bt broccoli plants

\begin{tabular}{llllllll}
\hline Genotype & $\begin{array}{l}\text { Plant } \\
\text { type }\end{array}$ & $\begin{array}{l}\text { Survival } \\
\text { rate }(\%)\end{array}$ & $\begin{array}{l}\text { Egg to larval } \\
\text { period (days) }\end{array}$ & $\begin{array}{l}\text { Pupal } \\
\text { rate }(\%)\end{array}$ & $\begin{array}{l}\text { Pupal weight } \\
(\mathrm{mg})\end{array}$ & $\begin{array}{l}\text { Pupal period } \\
\text { Adult emergence } \\
(\%)\end{array}$ \\
\hline $\mathrm{RR}$ & $\mathrm{Bt}$ & $93.8 \pm 2.40 \mathrm{a}$ & $10.6 \pm 0.11 \mathrm{a}$ & $85.0 \pm 2.89 \mathrm{a}$ & $7.3 \pm 0.26 \mathrm{a}$ & $3.1 \pm 0.07 \mathrm{a}$ & $92.4 \pm 3.03 \mathrm{a}$ \\
& Non-Bt & $95.0 \pm 3.54 \mathrm{a}$ & $10.1 \pm 0.04 \mathrm{ab}$ & $76.3 \pm 4.73 \mathrm{a}$ & $7.3 \pm 0.13 \mathrm{a}$ & $3.0 \pm 0.09 \mathrm{ab}$ & $90.3 \pm 1.53 \mathrm{a}$ \\
$\mathrm{RS}^{*}$ & Non-Bt & $92.5 \pm 3.23 \mathrm{a}$ & $9.9 \pm 0.22 \mathrm{~b}$ & $80.0 \pm 4.56 \mathrm{a}$ & $7.2 \pm 0.18 \mathrm{a}$ & $2.8 \pm 0.09 \mathrm{~b}$ & $93.8 \pm 2.74 \mathrm{a}$ \\
SS* & Non-Bt & $95.0 \pm 2.04 \mathrm{a}$ & $9.8 \pm 0.21 \mathrm{~b}$ & $87.5 \pm 3.23 \mathrm{a}$ & $7.5 \pm 0.08 \mathrm{a}$ & $2.6 \pm 0.11 \mathrm{~b}$ & $95.9 \pm 2.55 \mathrm{a}$ \\
$d f$ & & 3,12 & 3,12 & 3,12 & 3,12 & 3,12 & 3,12 \\
$F$ & 0.175 & 5.592 & 1.639 & 0.613 & 5.529 & 0.868 \\
$P$ & 0.912 & 0.014 & 0.233 & 0.619 & 0.015 & 0.484 \\
\hline
\end{tabular}

Means $( \pm$ SEM) within the same column followed by different letters are significantly different $(P<0.05$, Tukey test $)$

* No survivor of RS and SS fed on Bt broccoli

(mean $\pm \mathrm{SE})$, respectively $(F=0.618, d f=2,12$, $P=0.556)$.

Can D. insulare discriminate plant types hosting different genotypes of $P$. xylostella?

Because RS and SS larvae could not survive on Bt broccoli plants, no parasitoids emerged from these hosts. Parasitism rates caused by $D$. insulare were similar when RR larvae were on Bt broccoli (31.3 \pm $4.76 \%)$ and non-Bt broccoli $(34.9 \pm 8.52 \%)$. The parasitism rates on RS and SS larvae were $29.6 \pm$ $6.97 \%$ and $32.1 \pm 8.32 \%$, respectively, when these larvae were on non-Bt broccoli plants. There were no significant differences between the four treatments $(F=0.092, d f=3,20, P=0.964)$.

Effect of plants type and host genotype on the development of the $F_{1}$ parasitoid

When D. insulare parasitized RR, RS and SS genotype larvae fed $\mathrm{Bt}$ or non-Bt broccoli plants, the parasitoids developed normally to adults if the insect hosts were able to survive on Bt broccoli plants (Table 2). D. insulare parasitism rates, the developmental times from egg to adult and adult weights were not significantly different when $D$. insulare parasitized RR larvae on Bt broccoli, and RR, RS and SS on non-Bt broccoli. Pupal weights and adult longevity of $D$. insulare were similar when insects developed from the RR genotype on Cry1Ac broccoli and non-Bt broccoli plants, but there were some differences in pupal weights and adult longevity between RR on Cry1Ac broccoli and RS or SS on non-Bt broccoli.
Development of $\mathrm{F}_{2}$ parasitoids reared from different genotypes of $P$. xylostella exposed to Bt or non-Bt broccoli

Diadegma insulare adults developed from RR larvae that fed on Bt or non-Bt broccoli plants successfully parasitized susceptible P. xylostella (Table 3). $D$. insulare parasitism rates, developmental time, pupal weight, adult weight, and adult longevity were not significantly affected by plant types (Bt or non-Bt) or host resistance genotype.

Quantification of Cry1Ac in P. xylostella and in D. insulare

Cry1Ac levels in P. xylostella and in D. insulare are presented as $\mu \mathrm{g} / \mathrm{g}$ of fresh tissue and $\mu \mathrm{g} \times 10^{-3} /$ insect (Table 4). For the tissue data, the highest concentrations were detected in the larvae of $P$. xylostella. The Cry1Ac concentration in the second instar larvae was 16 times higher than in the pupae and 48 times higher than in the adult. The Cry1Ac levels in larvae and pupae of $D$. insulare were much lower than that of $P$. xylostella. Adults of $D$. insulare had very low levels of Cry1Ac (0.01), while a much high level (0.92) was detected in the pupal cocoons, presumably because the Cry1Ac was excreted with other waste in the pupal meconium.

Bioactivity of Cry1Ac after ingestion by $P$. xylostella larvae

The survival rate was $93 \% \pm 2.1$ and $91 \% \pm 2.3$ when the SS larvae fed on the leaf with the solution of non-Bt broccoli plants and on the leaf with 
Table 2 Development of F1 Diadegma insulare in different genotypes of Plutella xylostella fed on Cry1Ac or non-Bt broccoli

\begin{tabular}{lllllll}
\hline Genotype & $\begin{array}{l}\text { Plant } \\
\text { type }\end{array}$ & $\begin{array}{l}\text { Parasitism } \\
\text { rate }(\%)\end{array}$ & $\begin{array}{l}\text { Egg to adult } \\
\text { period (days) }\end{array}$ & $\begin{array}{l}\text { Pupae weight } \\
(\mathrm{mg})\end{array}$ & $\begin{array}{l}\text { Adult weight } \\
(\mathrm{mg})\end{array}$ & $\begin{array}{l}\text { Adult longevity } \\
(\mathrm{days})\end{array}$ \\
\hline $\mathrm{RR}$ & $\mathrm{Bt}$ & $86.7 \pm 2.92 \mathrm{a}$ & $13.7 \pm 0.11 \mathrm{a}$ & $5.1 \pm 0.13 \mathrm{a}$ & $1.2 \pm 0.03 \mathrm{ab}$ & $2.6 \pm 0.07 \mathrm{a}$ \\
& Non-Bt & $72.3 \pm 13.35 \mathrm{a}$ & $13.8 \pm 0.14 \mathrm{a}$ & $5.3 \pm 0.21 \mathrm{ab}$ & $1.1 \pm 0.03 \mathrm{ab}$ & $2.4 \pm 0.11 \mathrm{ab}$ \\
$\mathrm{RS}$ & Non-Bt & $78.2 \pm 7.49 \mathrm{a}$ & $14.1 \pm 0.12 \mathrm{a}$ & $5.7 \pm 0.13 \mathrm{~b}$ & $1.1 \pm 0.03 \mathrm{a}$ & $2.4 \pm 0.09 \mathrm{ab}$ \\
$\mathrm{SS}$ & Non-Bt & $87.8 \pm 2.0 \mathrm{a}$ & $14.0 \pm 0.14 \mathrm{a}$ & $5.6 \pm 0.17 \mathrm{ab}$ & $1.2 \pm 0.03 \mathrm{~b}$ & $2.4 \pm 0.05 \mathrm{~b}$ \\
$d f$ & & 3,12 & 3,221 & 3,107 & 3,197 & 3,194 \\
$\mathrm{~F}$ & & 1.361 & 1.655 & 3.258 & 2.717 & 3.778 \\
$P$ & & 0.305 & 0.178 & 0.024 & 0.046 & 0.012 \\
\hline
\end{tabular}

Means $( \pm$ SEM) within the same column followed by different letters are significantly different $(P<0.05$, Tukey test $)$

Table 3 Development of F2 D. insulare whose parents emerged from different genotypes of Plutella xylostella fed on Cry1Ac or non-Bt broccoli

\begin{tabular}{lllllll}
\hline $\begin{array}{l}\text { Parental } \\
\text { genotype }\end{array}$ & $\begin{array}{l}\text { Plant } \\
\text { type }\end{array}$ & $\begin{array}{l}\text { Parasitism } \\
\text { rate }(\%)\end{array}$ & $\begin{array}{l}\text { Developmental } \\
\text { time (days) }\end{array}$ & $\begin{array}{l}\text { Pupae weight } \\
(\mathrm{mg})\end{array}$ & $\begin{array}{l}\text { Adult weight } \\
(\mathrm{mg})\end{array}$ & $\begin{array}{l}\text { Adult longevity } \\
(\mathrm{days})\end{array}$ \\
\hline $\mathrm{RR}$ & $\mathrm{Bt}$ & $89.5 \pm 1.89 \mathrm{a}$ & $13.5 \pm 0.12 \mathrm{a}$ & $5.8 \pm 0.20 \mathrm{a}$ & $1.2 \pm 0.06 \mathrm{a}$ & $2.5 \pm 0.17 \mathrm{a}$ \\
& Non-Bt & $93.0 \pm 1.32 \mathrm{a}$ & $13.2 \pm 0.16 \mathrm{a}$ & $5.2 \pm 0.15 \mathrm{a}$ & $1.1 \pm 0.05 \mathrm{a}$ & $2.5 \pm 0.11 \mathrm{a}$ \\
$\mathrm{RS}$ & Non-Bt & $79.1 \pm 6.31 \mathrm{a}$ & $13.6 \pm 0.10 \mathrm{a}$ & $5.5 \pm 0.13 \mathrm{a}$ & $1.3 \pm 0.05 \mathrm{a}$ & $2.4 \pm 0.10 \mathrm{a}$ \\
SS & Non-Bt & $88.5 \pm 2.06 \mathrm{a}$ & $13.3 \pm 0.19 \mathrm{a}$ & $5.6 \pm 0.21 \mathrm{a}$ & $1.3 \pm 0.07 \mathrm{a}$ & $2.6 \pm 0.17 \mathrm{a}$ \\
$d f$ & & 3,12 & 3,113 & 3,117 & 3,43 & 3,102 \\
$F$ & & 2.854 & 1.373 & 2.245 & 1.063 & 0.204 \\
$P$ & & 0.105 & 0.255 & 0.087 & 0.375 & 0.894 \\
\hline
\end{tabular}

Means $( \pm$ SEM) within the same column followed by different letters are significantly different $(P<0.05$, Tukey test $)$

Table 4 Cry1Ac concentration in fresh Bt broccoli leaf and in Plutella xylostella and in Diadegma insulare (Means \pm SEM) $(n=5)$

\begin{tabular}{lcc}
\hline Sample & $\begin{array}{l}\text { Cry1Ac } \\
\text { concentration } \\
\text { per fresh g } \\
\text { tissue }(\mu \mathrm{g} / \mathrm{g})\end{array}$ & $\begin{array}{l}\text { Cry1Ac } \\
\text { concentration } \\
\text { per insect } \\
\left(\mu \mathrm{g} \times 10^{-3} / \mathrm{insect}\right)\end{array}$ \\
\hline Bt broccoli leaf & $12.33 \pm 1.618$ & - \\
2nd instar $P$. xylostella & $4.86 \pm 0.333$ & $0.99 \pm 0.061$ \\
3rd instar $P$. xylostella & $1.70 \pm 0.225$ & $3.15 \pm 0.413$ \\
4th instar $P$. xylostella & $1.89 \pm 0.189$ & $13.29 \pm 1.178$ \\
$P$. xylostella pupae & $0.31 \pm 0.025$ & $2.17 \pm 0.190$ \\
$P$. xylostella adult & $0.10 \pm 0.011$ & $0.32 \pm 0.038$ \\
D. insulare larvae & $0.15 \pm 0.027$ & $1.05 \pm 0.193$ \\
D. insulare pupae & $0.22 \pm 0.033$ & $1.23 \pm 0.202$ \\
D. insulare adult & $0.01 \pm 0.002$ & $0.01 \pm 0.004$ \\
D. insulare pupal coccon & $0.92 \pm 0.039$ & $1.10 \pm 0.046$ \\
\hline
\end{tabular}

extraction buffer, respectively. By comparison, the survival rate of SS insects was $51 \pm 4.0 \%$ when they fed on the cabbage leaf with the solution of Cry1Ac toxin ingested by RR larvae $(F=63.414, d f=2,27$, $P<0.0001)$, thus indicating the Cry1Ac was still active against susceptible $P$. xylostella.

\section{Discussion}

Biological control, using predators and parasitoids of crop pests, is a key component in integrated pest management (IPM) systems and these beneficial organisms should be conserved (Croft 1990). Another key element in IPM is host plant resistance, but we have had little host plant resistance to key lepidopteran and coleopteran species in our major crops prior to the advent of Bt crops (Shelton et al. 2008). A key question is whether host plant resistance using $\mathrm{Bt}$ technology is compatible with biological control.

There has been considerable published work in the laboratory and field on the potential effects of $\mathrm{Bt}$ proteins on natural enemies. The effects of Cry toxins on predators were reviewed by Romeis et al. (2006) 
and the authors suggested that predators were not susceptible to lepidopteran-active proteins. For example, Lawo et al. (2010) confirmed that Cry1Ac protein has no directly toxicity to the predator, Chrysoperla carnea, a predator others (e.g. Hilbeck et al. 1998) suggested was susceptible. For parasitoids the situation is more complex, whereas an insect predator is characterized by feeding on multiple and various hosts during its lifetime, a parasitoid usually completes its entire life in a single host and derives all its nutritional requirements from the host tissues. Sanders et al. (2007) reported that adult Campoletis sonorensis reared on Bt maize-fed Spodoptera frugiperda larvae were significantly smaller than those reared in hosts fed either of the conventional maize hybrids. Ramirez-Romero et al. (2007) assessed hostmediated effects of Cry1 Ab on the parasitoid Cotesia marginiventris and showed that the exposure to Cry1 Ab protein via Bt-maize tissue affected parasitoid developmental times, adult size, and fecundity. If hosts fed on Bt cotton or the diet with Cry1Ac toxin, the survival and development of the hymenopteran endoparasitoids were affected (Baur and Boethel 2003; Liu et al. 2005a, b, c; Ding et al. 2009). Although some (e.g. Romeis et al. 2006; Naranjo 2009) would argue that these negative impacts on parasitoids were likely due to poor host-quality, others may argue that the parasitoids were directly harmed by the Bt proteins. It is important to sort this out and the use of Bt-resistant hosts is the best way to do so. Demonstrating that the parasitoid is simply not susceptible to the $\mathrm{Bt}$ protein is best done using resistant hosts and showing that the protein that the parasitoid was exposed to was biologically active. The present study is the second example of such a critical test. However, unlike the first example by Chen et al. (2008), in this study we examined the effect of host genotypes, their interaction with plant type and any potential longer-term effect in subsequent generations.

In the present study, the life parameters of P. xylostella with resistance to Cry1Ac were not significantly different when the larvae fed on $\mathrm{Bt}$ broccoli and non-Bt broccoli. The heterozygous and susceptible larvae could not survive on the Bt broccoli plants (Table 1), which indicated that the Bt broccoli used in the present study was effective against susceptible $P$. xylostella. Our results also indicate that the Cry1Ac-resistant strain was highly resistant to Cry1Ac since most RR larvae could survive on the Cry1Ac broccoli plants, the larvae developed at a similar rate and the size of larvae parasitized by $D$. insulare was similar (Table 1). The equally high rates of parasitism by $D$. insulare when on RR hosts on Bt and non-Bt plants and when on RS and SS hosts on non-Bt plants suggest that Cry1Ac has no effect on $D$. insulare and there is also no indication of sublethal effects.

Diadegma insulare consumed most of its host's tissue before emergence and was thus exposed to toxins present in the gut of the host (Harvey and Strand 2002). In our study, Cry1Ac protein was detected in $D$. insulare, although the toxin was diluted when moving though the trophic levels. Furthermore, our result also confirmed the Cry1Ac protein the parasitoid was exposed to was still biologically active. Despite these findings, $D$. insulare parasitism rate, egg to adult period, pupal weight, adult weight and adult longevity were not affected when Bt broccoli-fed RR larvae were used as hosts. The fact that D. insulare did not complete its development when Bt broccoli-fed SS larvae were used as hosts was due to the earlier death of the susceptible P. xylostella on Bt broccoli plants rather than direct toxicity by Cry1Ac protein. Therefore, our present results further confirmed that this Cry protein is safe to this important parasitoid. Schuler et al. $(1999,2004)$ reported similar results in $P$. xylostella and another of its parasitoids, Cotesia plutella, that developed to maturity in Btresistant hosts fed on Bt oilseed rape leaves. However, in their study, they did not confirm the bioactivity of the ingested Cry protein nor make the assessment past the first generation.

Another facet of the present study is the potential interaction between parasitism and host resistance to Bt proteins. It has been reported that some strains of $P$. xylostella have developed resistance to microbial Bt sprays in the field (Shelton et al. 2007) and that resistant strains can also survive on Bt broccoli (Zhao et al. 2000). Thus, if Bt crucifers are deployed commercially (Shelton et al. 2008), it is possible there would be resistant, heterozygous and susceptible larvae in the fields. If there is a preference by a parasitoid to remove resistant individuals, then this would reduce the likelihood of the population becoming resistant to the Bt crop. In the present study, we addressed the question but our results indicated that $D$. insulare parasitism rates were not 
significantly different when RR, RS and SS larvae fed on non-Bt broccoli; therefore, we conclude that at least $D$. insulare could not discriminate different genotype hosts.

Host location and acceptance by parasitoids relies on a number of cues, such as volatiles released by plants in response to feeding damage and by insect frass (Turlings et al. 2005) and changes in these signals in plants may prevent parasitoids from locating hosts effectively (Sanders et al. 2007). However, Schuler et al. (1999, 2003) reported that C. plutella females did not distinguish between $\mathrm{Bt}$ and wild type oilseed rape plants, and were more attracted to Bt plants damaged by Bt-resistant hosts than by susceptible hosts due to more extensive feeding damage.

In our study, we examined the foraging behavior and host acceptance of $D$. insulare under the interactions of plant and insect hosts. The parasitism rates were not significantly different when a resistant host fed on Cry1Ac broccoli plants or when resistant, heterozygous and susceptible hosts fed on non-Bt broccoli plants. Therefore, we conclude that $D$. insulare could not discriminate between plant types (Bt or non-Bt), insect host genotypes (RR, RS, or SS) and any interaction effects of plant types and insect genotypes, which may have implications on the role of natural enemies regulating resistance evolution of target insect pests to Bt crops (Bates et al. 2005; Onstad and Knolhoff 2008).

In conclusion, transgenic Bt brasscia plants can effectively control $P$. xylostella but have no direct effects on hymenopteran parasitoids based on the results herein and those from our previous studies (Cao et al. 1999, 2002; Zhao et al. 2003; Chen et al. 2008). These conclusions were derived from experiments using our unique system of Bt broccoli and resistant $P$. xylostella. However, we expect that similar conclusions could be reached using other Bt crops and resistant insect species if they were available. If this broader conclusion could be verified, then we suggest that $\mathrm{Bt}$ plants are fully compatible with biological control within an overall integrated pest management program.

Acknowledgments We thank Yen Mei Cheung and Hilda L. Collins for technical assistance and Dr. Jian-zhou Zhao (Pioneer Hi-Bred International Inc., Johnston, Iowa) and Dr. Jörg Romeis (Agroscope ART, Switzerland) for reviewing an earlier version of the manuscript. The research was funded by US Department of Agriculture Biotechnology Risk Assessment Program Grant.

\section{References}

Atwood DW, Young SY, Kring TJ (1998) Mortality of tobacco budworm larvae (Lepidoptera: Noctuidae) and emergence of Cotesia marginiventris (Hymenoptera: Braconidae) exposed to Bacillus thuringiensis and thiodicarb alone and in combination. J Econ Entomol 33:136-141

Avisar D, Keller M, Gazit E, Prudovsky E, Sneh B, Aviah Z (2004) The role of Bacillus thuringiensis Cry1C and Cry1E separate structural domains in the interaction with Spodoptera littoralis gut epithelial cells. J Biol Chem 279(16):15779-15786

Bates SL, Zhao J-Z, Roush RT, Shelton AM (2005) Insect resistance management in GM crops: past present and future. Nat Biotech 23:57-62

Baur ME, Boethel DJ (2003) Effect of Bt-cotton expressing Cry1A(c) on the survival and fecundity of two hymenoptera parasitoids (Braconidae: Encyrtidae) in the laboratory. Biol Control 26:325-332

Brookes G, Barfoot P (2010) Global impact of biotech crops: environmental effects, 1996-2008. AgBioForum 13:76-94

Cao J, Tang JD, Strizhov N, Shelton AM, Earle ED (1999) Transgenic broccoli with high levels of Cry1C protein control diamondback moth larvae resistant to Cry1A or Cry1C. Mol Breed 5:131-141

Cao J, Zhao JZ, Tang JD, Shelton AM, Earle ED (2002) Broccoli plants with pyraminded crylAc and cry $1 C \mathrm{Bt}$ genes control diamondback moth resistant to Cry1A and Cry1C protein. Theor Appl Genet 105:258-264

Cao J, Shelton AM, Earle ED (2005) Development of transgenic collards expressing a cry1Ac or cry1C Bt gene for control of the diamondback moth. Crop Prot 24:804-813

Chen M, Zhao JZ, Collins HL, Earle ED, Cao J, Shelton AM (2008) A critical assessment of the effects of Bt transgenic plants on parasitoids. PLoS ONE 3(5):e2284. doi:10.1371/ journal.pone.0002284

Croft BA (1990) Arthropod biological control agents and pesticides. Wiley, New York

Ding J, Li JC, Liu XX, Zhang QW (2009) The life parameters of a parasitoid Microplitis mediator (Hymenoptera:Braconidae), reared on cotton bollworm Helicoverpa armigera (Hübner) with Cry1Ac diet. Biocontrol Sci Technol 19:931-941

Grzywacz D, Rossbach A, Rauf A, Russell D, Srinivasan R, Shelton AM (2010) Current control methods for diamondback moth and prospects for improved management with lepidopteran-resistant Bt vegetable brassicas in Asia and Africa. Crop Prot 29:68-79

Harvey JA, Strand MR (2002) The development strategies of endoparasitoid wasps vary with host feeding ecology. Ecology 83:2439-2451

Hilbeck A, Baumgartner M, Fried PM, Bigler F (1998) Effects of transgenic Bacillus thuringiensis corn-fed prey on mortality and development time of immature Chrysoperla carnea (Neuroptera: Chrysopidae). Envion Entomol $27: 480-487$ 
James C (2009) Global status of commercialized transgenic crops: Bt cotton, ISAAA Briefs No. 39. International Service for the Acquisition of Agri-biotech Applications, Ithaca

Johnson MT (1997) Interaction of resistant plants and wasp parasitoids of tobacco budworm (Lepidoptera: Noctuidae). Environ Entomol 2:207-214

Lawo NC, Wäckers FL, Romeis J (2010) Characterizing indirect prey quality mediated effects of a $\mathrm{Bt}$ crop on predatory larvae of the green lacewing, Chrysoperla carnea. J Insect Physiol 56:1702-1710

Liu XX, Sun CG, Zhang QW (2005a) Effects of transgenic Cry1A + CpTI cotton and Cry1Ac toxin on the parasitoid, Campoketis chlorideae (Hymenoptera: Ichneumonidae). Insect Sci 12:101-107

Liu XX, Zhang QW, Zhao JZ, Cai QN, Xu HL, Li JC (2005b) Effects of the Cry1Ac toxin of Bacillus thuringiensis on Microplitis mediator (Haliday) (Hymenoptera: Braconidae), a parasitoid of the cotton bollworm, Helicoverpa armigera (Hübner). Entomol Exp Appl 114:205-213

Liu XX, Zhang QW, Zhao JZ, Li JC, Xu BL, Ma XM (2005c) Effects of Bt transgenic cotton lines on the cotton bollworm parasitoid Microplitis mediator in the laboratory. Biol Control 35:134-141

Lövei GL, Andow DA, Arpaia S (2009) Transgenic insecticidal crops and natural enemies: a detailed review of laboratory studies. Environ Entomol 38:293-306

Metz TD, Roush RT, Tang JD, Shelton AM, Earle ED (1995) Transgenic broccoli expressing a Bacillus thuringiensis insecticidal crystal protein: implications for pest resistance management strategies. Mol Breed 1:309-317

Naranjo SE (2009) Impacts of Bt crops on non-target organisms and insecticide use patterns. CAB Reviews: Perspect Agric Vet Sci Nutrit Nat Resour 4:No.011. (doi:10.1079/ PAVSNNR20094011)

Onstad DW, Knolhoff L (2008) Arthropod resistance to crops. Chapter 9. In: Onstad DW (ed) Insect resistance management: biology, economics and prediction. Academci Press. pp 185-208

Qaim M, Pray CE, Zilberman D (2008) Economic and social considerations in the adoption of Bt crops. In: Romeis J, Shelton AM, Kennedy GG (eds) Integration of insectresistant genetically modified crops within IPM programs. Springer, Dordrecht, pp 329-356

Ramirez-Romero R, Bernal JS, Chaufaux J, Kaiser L (2007) Impact assessment of Bt-maize on a moth parasitoid, Cotesia marginiventris (Hymenoptera: Braconidae), via host exposure to purified Cry1 Ab protein or Bt-plants. Crop Prot 26:953-962

Romeis J, Meissle M, Bigler F (2006) Transgenic crops expressing Bacillus thuringiensis toxins and biological control. Nat Biotechnol 24:63-71

Romeis J, Hellmich RL, Candolfi MP, Carstens K, Schrijver AD, Gatehouse AMR, Herman RA, Huesing JE, McLean MA, Raybould A, Shelton AM, Waggoner A (2010) Recommendations for the design of laboratory studies on non-target arthropods for risk assessment of genetically engineered plants. Transgenic Res doi:10.1007/s11248010-9446-X

Sanders CJ, Pell JK, Poppy GM, Raybould AR, Garcia-Alonso M, Schuler TH (2007) Host-plant mediated effects of transgenic maize on the insect parasitoid Campoletis sonorensis (Hymenoptera: Ichneumonidae). Biol Control 40:362-369

Sarfraz M, Keddie BA, Dosdall LM (2005) Biological control of the diamondback moth, Plutella xylostella (L.): a review. Biocontrol Sci Technol 15:763-789

Schuler TH, Potting RPJ, Denholm I, Poppy GM (1999) Parasitoid behaviour and Bt plants. Nature 400:825-826

Schuler HT, Potting RPJ, Denholm I, Clark SJ, Clark AJ, Stewart CN, Poppy GM (2003) Tritrophic choice experiments with Bt plants, the diamondback moth (Plutella xylostella) and the parasitoid Cotesia plutellae. Transgenic Res 12:351-361

Schuler TH, Denholm I, Clark SJ, Stewart CN, Poppy GM (2004) Effects of Bt plants on the development and survival of the parasitoid Cotesia plutellae (Hymenoptera: Braconidae) in susceptible and Bt-resistant larvae of the diamondback moth, Plutella xylostella (Lepidoptera: Plutellidae). J Insect Physiol 50:435-443

Shelton AM, Kroening MK, Wilsey WT, Eigenbrode SD (1991) Comparative analysis of two rearing procedures for diamondback moth, Plutella xylostella (Lepidoptera: Plutellidae). J Entomol Sci 26:17-26

Shelton AM, Tang JD, Roush RT, Metz TD, Earle ED (2000) Field tests on managing resistance to Bt-engineered plants. Nat Biotech 18:339-342

Shelton AM, Zhao J-Z, Roush RT (2002) Economic, ecological, food safety, and social consequences of the deployment of $B t$ transgenic plants. Annu Rev Entomol 47:845-881

Shelton AM, Roush RT, Wang P, Zhao J-Z (2007) Resistance to insect pathogens and strategies to manage resistance: an update. In: Lacey LA, Kaya HK (eds) Field manual of techniques in invertebrate pathology, 2nd edn. Kluwer, Dordrecht, pp 793-811

Shelton AM, Romeis J, Kennedy GG (2008) IPM and insectprotected transgenic plants: thoughts for the future. In: Romeis J, Shelton AM, Kennedy GG (eds) Integration of insect-resistant, genetically modified crops within IPM programs. Springer, Dordrecht, pp 419-429

Shelton AM, Naranjo SE, Romeis J, Hellmich RL, Wolt JD, Federici BA, Albajes R, Bigler F, Burgess EPJ, Dively GP, Gatehouse AMR, Malone LA, Roush R, Sears M, Sehnal F (2009a) Setting the record straight: a rebuttal to an erroneous analysis on transgenic insecticidal crops and natural enemies. Transgenic Res 18:317-322

Shelton AM, Naranjo SE, Romeis J, Hellmich RL, Wolt JD, Federici BA, Albajes R, Bigler F, Burgess EPJ, Dively GP, Gatehouse AMR, Malone LA, Roush R, Sears M, Sehnal F, Ferry N, Bell HA (2009b) Appropriate analytical methods are necessary to assess nontarget effects insecticidal proteins in GM crops through Meta-analysis. Environ Entomol 38(6):1533-1538

SPSS (1998) SPSS user's guide. SPSS Inc., Chicago

Talekar NS, Shelton AM (1993) Biology, ecology, and management of the diamondback moth. Annu Rev Entomol 38:275-301

Tang JD, Collins HL, Roush RT, Metz TD, Earle ED, Shelton AM (1999) Survival, weight gain, and oviposition of resistant and susceptible Plutella xylostella (L.) (Lepidoptera: Plutellidae) on broccoli expressing Cry1Ac toxin of Bacillus thuringiensis. J Econ Entomol 92:47-55 
Tang JD, Collins HL, Metz TD, Earle ED, Zhao J-Z, Roush RT, Shelton AM (2001) Greenhouse tests on resistance management of Bt transgenic plants using refuge strategies. J Econ Entomol 94:240-247

Turlings TCJ, Jeanbourquin PM, Held M, Degen T (2005) Evaluating the induced-odour emission of a Bt maize and its attractiveness to parasitic wasps. Transgenic Res 14:807-816

Xu JX, Shelton AM, Cheng XN (2001a) Comparison of Diadegma insulare (Hymenoptera: Ichneumonidae) and Microplitis plutellae (Hymenoptera : Braconidae) as biological control agents of Plutella xylostella (Leptidoptera : Plutellidae): field parasitism, insecticide susceptibility, and host-searching. J Econ Entomol 94:14-20

Xu JX, Shelton AM, Cheng XN (2001b) Variation in susceptibility of Diadegma insulare (Hymenoptera: Ichneumonidae) to permethrin. J Econ Entomol 94:541-546
Zhao JZ, Collins HL, Tang JD, Cao J, Earle ED, Roush RT et al (2000) Development and characterization of diamondback moth resistance to transgenic broccoli expressing high levels of Cry1C. Appl Environ Microbiol 66:3784-3789

Zhao J, Cao J, Li Y, Collins HL, Roush RT, Earle ED, Shelton AM (2003) Plants expressing two Bacillus thuringiensis toxins delay insect resistance compared to single toxins used sequentially or in a mosaic. Nat Biotech 21:1493-1497

Zhao JZ, Cao J, Collins HL, Bates SL, Roush RT, Earle ED, Shelton AM (2005) Concurrent use of transgenic plants expressing a single and two Bacillus thuringiensis genes speeds insect adaptation to pyramided plants. Proc Natl Acad Sci USA 102:8426-8430 